\title{
APPLICATION OF LACTOCOCCIN BZ AND ENTEROCIN KP AGAINST LISTERIA MONOCYTOGENES IN MILK AS BIOPRESERVATION AGENTS
}

\author{
Z. YILDIRIM ${ }^{a *}$, N. ÖNCÜL ${ }^{b}$, M. YILDIRIM ${ }^{a}$ and Ş. KARABIYIKLI ${ }^{b}$

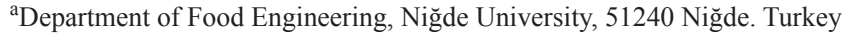 \\ ${ }^{b}$ Department of Food Engineering, Gaziosmanpaşa University, 60250 Taşliçiftlik, Tokat. Turkey
}

(Received: 12 January 2016; accepted: 7 May 2016)

\begin{abstract}
This study was performed to evaluate the effect of lactococcin BZ and enterocin KP against Listeria monocytogenes ATCC 7644 in skim $(0.1 \%)$, half (1.5\%), and full fat (3.0\%) UHT milks. The milk samples were inoculated with L. monocytogenes at the level of approximately $2.60,4.76$, and $6.45 \log \mathrm{CFU} \mathrm{m}^{-1}$, and then treated with various concentrations $\left(400,800,1600\right.$, or $\left.2500 \mathrm{AU} \mathrm{ml}^{-1}\right)$ of lactococcin BZ, enterocin $\mathrm{KP}$, or their combination (1:1). Lactococcin BZ at $400-2500 \mathrm{AU} \mathrm{m}^{-1}$ level displayed strong antilisterial activity, and decreased the viable cell numbers of $L$. monocytogenes to an undetectable level in all types of milk samples during the entire storage periods at $4{ }^{\circ} \mathrm{C}$ or $20^{\circ} \mathrm{C}$. Enterocin KP also had a high antilisterial effect, but it decreased as both the fat content of milk and inoculation amount of $L$. monocytogenes increased.
\end{abstract}

Keywords: bacteriocin, lactococcin BZ, enterocin KP, Listeria monocytogenes, milk

Milk and dairy products could be easily contaminated with foodborne pathogens such as Listeria monocytogenes under poor hygienic conditions. L. monocytogenes is an intracellular, facultative anaerobic, psychrotrophic and opportunistic pathogenic bacterium, which causes listeriosis. Listeriosis is a serious foodborne disease for newborns and infants, pregnant women or immunocompromised people (Jemmi \& Stephan, 2006). Listeriosis has been associated with raw milk, pasteurized milk, and other dairy products, vegetables, and meat products. Because of its resistance to thermal, drying, and freezing processes, it can be a serious threat especially in dairy products. Outbreaks of human infections associated with consumption of dairy products have occurred with increased frequency during the past decade (Jemmi \& Stephan, 2006; Kim et al., 2008).

One of the current trends in food preservation is biopreservation. Biopreservation refers to extended storage life and enhanced safety of foods using the natural microflora or their antibacterial products (STILES, 1996). Bacteriocins produced by lactic acid bacteria are one of the most important biopreservatives due to their proteinaceous nature and inhibitory effect against foodborne pathogens and spoilage bacteria (DEEGAN et al., 2006).

In previous studies, we isolated two bacteriocinogenic strains, Lactococcus lactis spp. lactis BZ and Enterococcus faecalis KP, from traditionally produced Boza and White cheese (ŞAHINGIL et al., 2011; IsLeroglu et al., 2012). Lactococcin BZ produced by L. lactis spp. lactis BZ has antibacterial activity against either Gram-positive or Gram-negative bacteria, including some strains of Listeria, Bacillus, Enterobacter, Escherichia, Salmonella, Yersinia, Citrobacter, Lactobacillus, Enterococcus, and Leuconostoc (ŞAHINGIL et al., 2011). Enterocin

* To whom correspondence should be addressed.
Phone: +90 388 2252354; fax: +93 388 2250112; e-mail: zeliha.yildirim@nigde.edu.tr

0139-3006/\$20.00 C 2016 Akadémiai Kiadó, Budapest 
KP produced by E. faecalis KP is active against only Gram-positive bacteria such as some strains of Listeria, Bacillus, Enterococcus, Lactobacillus, Leuconostoc, and Lactococcus (IsLEROGLu et al., 2012).

The objective of this study was to investigate the antimicrobial effects of lactococcin BZ and enterocin KP by itself or in combination toward L. monocytogenes in skim $(0.1 \%)$, half fat $(1.5 \%)$, and full fat $(3.0 \%)$ milks.

\section{Materials and methods}

\subsection{Materials}

Skim $(0.1 \%)$, half fat $(1.5 \%)$, and full fat $(3.0 \%)$ UHT milks were obtained from local supermarkets and they were stored at $4-5^{\circ} \mathrm{C}$ in their original aseptic packages until used.

L. lactis spp. lactis BZ and E. faecalis KP were grown in de Man Rogosa and Sharpe Medium (MRS, Fluka, Germany) and stocked at $-80{ }^{\circ} \mathrm{C}$ in MRS broth containing $20 \%$ glycerol. Brain Heart Infusion (BHI, Merck, Germany) broth was used for culturing L. monocytogenes ATCC 7644, and it was kept at $-80{ }^{\circ} \mathrm{C}$ in BHI broth containing $20 \%$ glycerol.

\subsection{Methods}

1.2.1. Bacteriocin production. L. lactis spp. lactis BZ and E. faecalis KP cultures were grown in MRS broth at $30{ }^{\circ} \mathrm{C}$ and $25^{\circ} \mathrm{C}$ for $18 \mathrm{~h}$, respectively (ŞAHINGIL et al., 2011; IsLEROGLU et al., 2012). At the end of incubation, each culture was centrifuged (Beoco, Germany) at $7000 \times g$ for $20 \mathrm{~min}$, and the supernatant was sterilized by membrane filtration $(0.45 \mu \mathrm{m})$. Both bacteriocins were partially purified by ammonium sulphate precipitation $(50 \%$ of saturation) and then organic solvent precipitation (methanol/chloroform mixture, 1:2, v/v) (Moreno et al., 2002). During each step of the bacteriocin preparation, the bacteriocin activity was tested against L. monocytogenes by using agar spot method mentioned previously by ISLEROGLU and co-workers (2012).

1.2.2. Inhibitory effect of bacteriocins toward L. monocytogenes in milk samples. Skim, half fat, and full fat milk samples were divided into $100 \mathrm{ml}$ portions under aseptic conditions, inoculated with various doses of $L$. monocytogenes (approximately 102, 10 $0^{4}$, and $10^{6}$ CFU ml $\mathrm{m}^{-1}$ ) and then treated with different concentrations $(400,800,1600$, and 2500 $\mathrm{AU} \mathrm{ml^{-1 }}$ ) of lactococcin BZ, enterocin $\mathrm{KP}$, or their combination $(1: 1$, total activity 400,800 , 1600 , or $2500 \mathrm{AU} \mathrm{ml}^{-1}$ ). The samples were stored for 25 days at $4{ }^{\circ} \mathrm{C}$ or $20^{\circ} \mathrm{C}$. During storage period, cell numbers of $L$. monocytogenes were determined on PALCAM agar (Sigma, Germany) after incubation at $37^{\circ} \mathrm{C}$ for $24-48 \mathrm{~h}$. The milk samples without bacteriocins and L. monocytogenes or containing just bacteriocin or L. monocytogenes were used as control samples.

1.2.3. Statistical analyses. Three replicates were done for each experiment. All data were analysed using the general linear models procedure of SAS InSTITUTE INC. (1998) in order to determine differences between treatment means. Pairwise comparisons of all treatment means were achieved by using Least Significant Difference (LSD) procedure at $\mathrm{P}<0.05$. 


\section{Results and discussion}

\subsection{Effect of bacteriocins on the survival of $\mathrm{L}$. monocytogenes in milk samples stored at $4{ }^{\circ} \mathrm{C}$}

Lactococcin BZ at all treatment levels (400-2500 $\mathrm{AU} \mathrm{ml}^{-1}$ ) decreased Listeria counts in all kinds of milk samples containing 2.53, 4.76, and $6.44 \log \mathrm{CFU} \mathrm{ml^{-1 }}$ to an undetectable level during the storage period. Inhibitory effect of enterocin KP was similar to that of lactococcin $\mathrm{BZ}$ in all milk samples inoculated with $2.53,4.76$, and $6.44 \log \mathrm{CFU} \mathrm{ml^{-1 }}$ when it was used at the concentrations of 800,1600 , or $2500 \mathrm{AU} \mathrm{ml}^{-1}$. Antilisterial activity of enterocin KP at 400 $\mathrm{AU} \mathrm{m} \mathrm{m}^{-1}$ decreased by increasing the amount of $L$. monocytogenes or the fat content of the milk. Enterocin KP at $400 \mathrm{AU} \mathrm{ml}^{-1}$ reduced Listeria counts to an undetectable level from day 0 to day 25 of the storage in all milk types inoculated with $2.53 \log \mathrm{CFU} \mathrm{ml}^{-1}$. At the same level, enterocin KP decreased Listeria counts to an undetectable level at day 3, 12, and 15 in skim, half fat, and full fat milk samples containing $4.76 \log \mathrm{CFU} \mathrm{m}{ }^{-1}$, respectively. However, similar reduction in Listeria counts with the same enterocin KP concentration was achieved at day 15 in skim milk inoculated with $6.44 \log \mathrm{CFU} \mathrm{ml}{ }^{-1}$ (Table 1). Additionally, enterocin $\mathrm{KP}$ at the same concentration did not reduce Listeria counts to an undetectable level even after 15 days storage in half and full fat milk samples containing $6.44 \log \mathrm{CFU} \mathrm{ml}{ }^{-1}$. At the end of 25 days storage, half fat and full fat milk samples still contained 1.55 and $1.76 \mathrm{log}$ CFU ml ${ }^{-1}$ Listeria, respectively (Table 1). Unlike enterocin KP, the fat content of the milk samples did not affect the activity of lactococcin BZ, probably because of its low hydrophobicity. These results showed that milk fat is not an important factor for biological activity of lactococcin BZ; however, it is an important factor for enterocin KP. Lactococcin BZ activity being unaffected by fat content could be quite important for food industry, especially for dairy industry. This result indicates that lactococcin BZ could be a good alternative antimicrobial agent to control pathogens in foods containing fat. Similar to enterocin KP, the inhibitory activity of nisin (Jung et al., 1992; B HATTI et al., 2004; MeENA et al., 2004; Yoon et al., 2011) and pediocin 5 from Pediococcus acidilactici UL5 (HuAng et al., 1994) declined by increasing fat content of dairy products. According to those authors, the decrease in bacteriocin activity was probably due to the fact that bacteriocin might be adsorbed to the milk fat globules and become unavailable to destroy bacterial cells.

The antilisterial activity of lactococcin BZ or enterocin KP is higher than those of the bacteriocins studied previously such as cerein A8 and nisin. The addition of $160 \mathrm{AU} \mathrm{ml} \mathrm{m}^{-1}$ cerein 8 A produced by $B$. cereus to UHT milk resulted in a decrease of 3 log cycles in the cell counts of $L$. monocytogenes within the 14-day period at $4{ }^{\circ} \mathrm{C}$ (BIZANI et al., 2008). Nisin (50 $\mathrm{IU} \mathrm{ml^{-1 }}$ ) caused 7, 3, and $1 \log$ reduction in the counts of L. monocytogenes Scott A in skim milk ( $0 \%$ fat), milk with $4 \%$ fat, and milk containing $12.9 \%$ fat, respectively (JunG et al., 1992). Most of the studies declared that cell counts of L. monocytogenes in milk challenged with different concentrations of nisin (BнAтTI et al., 2004; KIM et al., 2008; Yoon et al., 2011) or pediocin 5 (HuANG et al., 1994) decreased to an undetectable level at the beginning of the incubation, but then increased during the incubation period.

The cell count of $L$. monocytogenes in the milk samples decreased abruptly as soon as lactococcin BZ and enterocin KP in combination (1:1, total activity 400, 800, 1600, or 2500 $\mathrm{AU} \mathrm{ml} \mathrm{m}^{-1}$ ) was added. Cell numbers decreased to undetectable level in skim, half fat, and full fat milk samples containing 2.53, 4.76, and $6.44 \log \mathrm{CFU} \mathrm{m}^{-1}$ Listeria cells. It was observed that when enterocin KP was used with lactococcin BZ (total bacteriocin activity 400 $\mathrm{AU} \mathrm{ml^{-1 }}$ ), the antilisterial effect increased in full fat and half fat milk containing 6.44 log unit L. monocytogenes compared to $400 \mathrm{AU} \mathrm{ml}^{-1}$ of enterocin $\mathrm{KP}$ used alone (Table 1). 


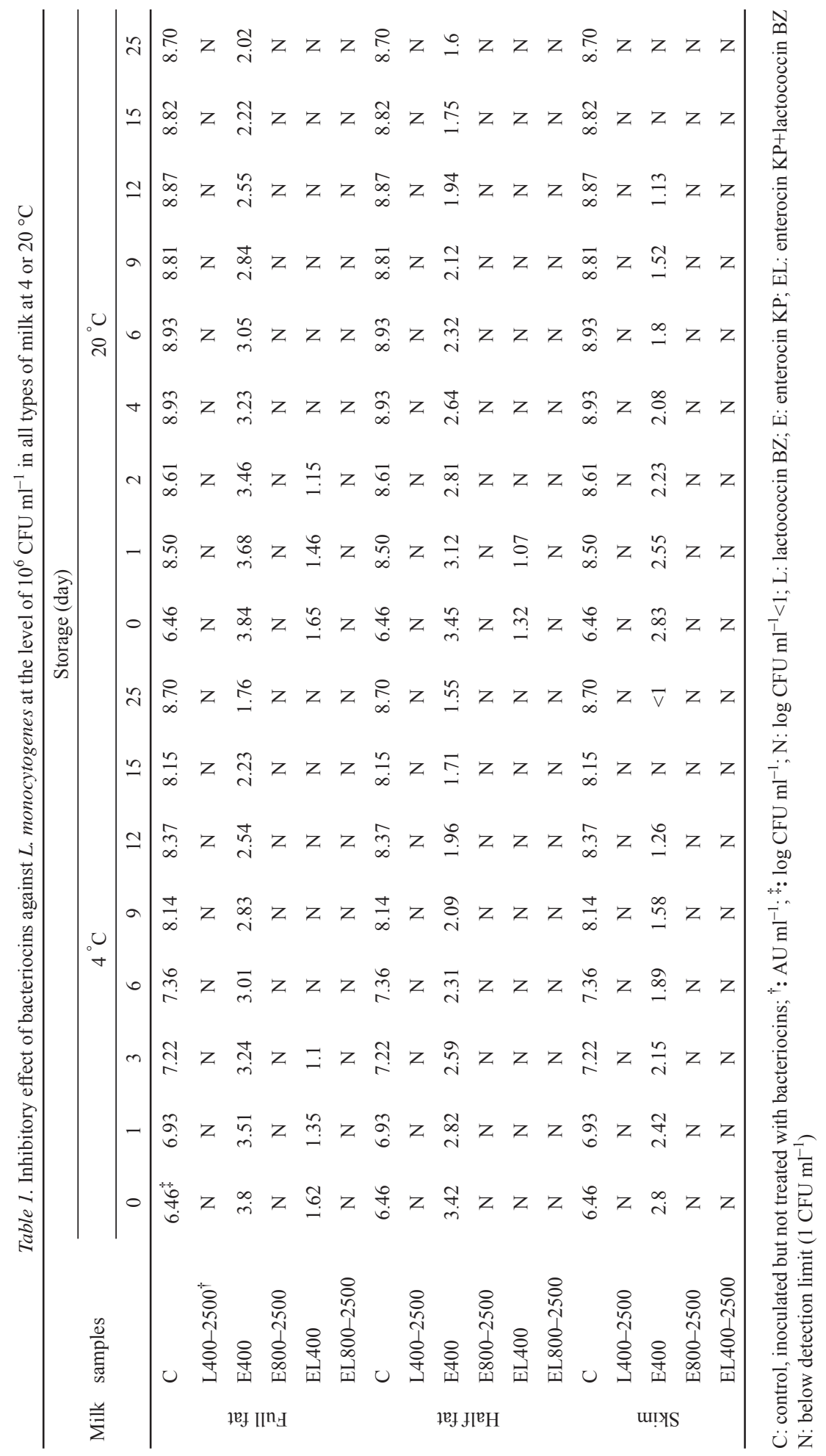


The initial counts of L. monocytogenes in the control samples increased from 2.53, 4.76, and $6.44 \log \mathrm{CFU} \mathrm{ml}{ }^{-1}$ to $7.73,7.63$, and $8.57 \log \mathrm{CFU} \mathrm{ml}{ }^{-1}$ by the end of the storage period. Also, lactococcin BZ and enterocin KP maintained their activities in all milk samples throughout storage period.

2.2. Effect of bacteriocins on the survival of $\mathrm{L}$. monocytogenes in milk samples stored at $20^{\circ} \mathrm{C}$

The results of challenge tests at $20{ }^{\circ} \mathrm{C}$ were similar to those at $4{ }^{\circ} \mathrm{C}$. Lactococcin $\mathrm{BZ}$ at concentrations of 400-2500 AU ml ${ }^{-1}$ showed very strong antilisterial activity and decreased the numbers of $L$. monocytogenes to an undetectable level in skim, half fat, and full fat milk samples containing 2.66, 4.77, and $6.45 \log \mathrm{CFU} \mathrm{m}{ }^{-1}$ Listeria, and no cell growth was observed during storage period (25 days). In all treated groups, enterocin KP at 800-2500 $\mathrm{AU} \mathrm{ml}{ }^{-1}$ resulted in a drastic decline in the initial cell numbers immediately after addition and no cell growth of $L$. monocytogenes was observed over the entire storage period. Enterocin $\mathrm{KP}$ at $400 \mathrm{AU} \mathrm{ml}^{-1}$ level reduced cell counts of $L$. monocytogenes to uncountable level in all kinds of milk samples containing L. monocytogenes at the level of $2.66 \log$ unit. The same concentration ( $400 \mathrm{AU} \mathrm{ml}^{-1}$ ) of enterocin $\mathrm{KP}$ in skim, half fat, and full fat milk containing $L$. monocytogenes at the level of $4.77 \log$ units reduced Listeria counts to an undetectable level on the $2^{\text {nd }}, 9^{\text {th }}$, and $15^{\text {th }}$ day of storage, respectively. However, enterocin KP at the level of 400 AU ml ${ }^{-1}$ in skim, half fat, and full fat milk containing L. monocytogenes at the level of 6.45 $\log$ unit reduced the colony counts of Listeria by $3.91,3.34$, and $2.78 \log$ units on $1^{\text {st }}$ day of storage, respectively. In these samples, cell numbers of Listeria decreased during the full incubation period (25 days) (Table 1). The effect of decreased activity of enterocin KP in milk sample with high Listeria cell counts and high milk fat content could be prevented by increasing the amount of enterocin KP added.

Combination of enterocin KP with lactococcin $\mathrm{BZ}$ at the ratio of 1:1 (total bacteriocin activity 400-2500 $\mathrm{AU} \mathrm{m}^{-1}$ ) led to a decrease in Listeria counts to undetectable level in all challenged skim, half fat, and full fat milk samples containing 2.66 and $4.77 \log \mathrm{CFU} \mathrm{ml}^{-1}$ at day 0. In full fat and half fat milk samples containing Listeria of $6.45 \log \mathrm{CFU} \mathrm{ml}^{-1}$, the edition of mixture of enterocin KP and lactococcin $\mathrm{BZ}$ at the level of total bacteriocin activity 800-2500 AU ml ${ }^{-1}$ decreased Listeria cell numbers to the undetectable level. In the same samples, mixture of both bacteriocins used at $400 \mathrm{AU} \mathrm{ml}^{-1}$, the numbers of $L$. monocytogenes declined to 1.32 and $1.65 \log$ units on the ${ }^{\text {st }}$ day of storage, and to undetectable level on the after $2^{\text {nd }}$ and $4^{\text {th }}$ days, respectively (Table 1). It was observed that enterocin KP and lactococcin $\mathrm{BZ}$ maintained their biological activities in all milk samples.

WAN and co-workers (1997) reported that piscicolin at a concentration as low as 512 $\mathrm{AU} \mathrm{ml} \mathrm{l}^{-1}$ effectively inhibited the growth of $L$. monocytogenes $\left(10^{2} \mathrm{CFU} \mathrm{m}{ }^{-1}\right)$ for the duration of the experiment (20 days) in whole milk. At higher challenge levels of L. monocytogenes $\left(10^{4}\right.$ and $\left.10^{6} \mathrm{CFU} \mathrm{ml}^{-1}\right)$, piscicolin $\left(2048 \mathrm{AU} \mathrm{ml}^{-1}\right)$ caused a reduction in the viable count of L. monocytogenes by more than $4 \log \mathrm{CFU} \mathrm{ml}{ }^{-1}$ after addition. However, they observed that L. monocytogenes started to re-grow within $24 \mathrm{~h}$. Also, piscicolin 126 at higher challenge levels (4096 and $8192 \mathrm{AU} \mathrm{ml}^{-1}$ ) did not bring about complete inhibition of $L$. monocytogenes further than day 1.

Storage temperature $\left(4{ }^{\circ} \mathrm{C}\right.$ or $\left.20^{\circ} \mathrm{C}\right)$ did not affect significantly antilisterial activity of lactococcin BZ, enterocin KP, or the combination of the two ( $P>0.05)$. At both storage temperatures, lactococcin $\mathrm{BZ}$ and enterocin $\mathrm{KP}$ showed strong and very quick antilisterial activity. However, some researchers found that the antibacterial activities of bacteriocins 
were more pronounced at $5-8{ }^{\circ} \mathrm{C}$ than at room temperature, and also high storage temperature and long storage time cause a loss of bacteriocin activity (Delves-Broughton et al., 1996).

In control samples containing only $L$. monocytogenes, the cell number increased from 2.66, 4.77, and $6.45 \log \mathrm{CFU} \mathrm{m} l^{-1}$ to $8.76,8.72$, and $8.75 \log \mathrm{CFU} \mathrm{ml}^{-1}$, respectively, by the end of the storage period.

\section{Conclusions}

Lactococcin BZ and enterocin KP by itself or their combination have strong antilisterial activity toward L. monocytogenes for all inoculum doses tested (2.53-2.66, 4.77-4.76, and 6.44-6.45 $\log$ CFU ml ${ }^{-1}$ ) in all kinds of milk samples (skim, half fat, and full fat milk) at two storage temperatures $\left(4^{\circ} \mathrm{C}\right.$ and $\left.20^{\circ} \mathrm{C}\right)$. Also, their effects are stable until the end of the tested storage periods. However, the low treatment dose of enterocin KP was found less effective than lactococcin BZ under the same conditions. It was also detected that by increasing treatment dose, the test microorganism could successfully be inhibited. Biological activity of lactococcin BZ was not adversely affected by milk fat content, whereas the activity of enterocin KP decreased with the increasing milk fat content. This could be overcome by increasing the concentration of enterocin KP or applying enterocin KP together with lactococcin BZ. The experimental application of lactococcin BZ, enterocin KP, and their combination separately into full fat, half fat, and skim milk to inhibit L. monocytogenes resulted in a bactericidal and strong antilisterial effect towards this foodborne pathogen. These results indicate that both bacteriocins may be successful alternatives as biopreservative agents in extending hygienic safety of foods, especially dairy foods.

Financial support for this research (scientific research project) was provided by Gaziosmanpasa University (Project no: 2008-50, Tokat, Turkey).

\section{References}

Bhatti, M., Veeramachaneni, A. \& Shelef, L.A. (2004): Factors affecting the antilisterial effects of nisin in milk. Int. J. Food Microbiol., 97, 215-219.

Bizani, D., Morrissy, J.A.C., Dominguez, A.P.M. \& Brandelli, A. (2008): Inhibition of Listeria monocytogenes in dairy products using the bacteriocin-like peptide cerein 8A. Int. J. Food Microbiol., 121, 229-233.

Deegan, L.H., Cotter, P.D., Hill, C. \& Ross, P. (2006): Bacteriocins: biological tools for bio-preservation and shelflife extension. Int. Dairy J., 16, 1058-1071.

Delves-Broughton, J., Blackburn, P., Evans, R.J. \& Hugenholtz, J. (1996): Applications of the bacteriocin, nisin. A. Van Leeuw. J. Microb., 69, 193-202.

Huang, J., Lacroix, C., Daba, H. \& Simard, R.E. (1994): Growth of Listeria monocytogenes in milk and its control by pediocin 5 produced by Pediococcus acidilactici UL5 Int. Dairy J., 4, 429-443.

Isleroglu, H., Yildirim, Z., Tokatli, M., Oncul, N. \& Yildirim, M. (2012): Partial characterisation of enterocin KP produced by Enterococcus faecalis KP, a cheese isolate. Int. J. Dairy Technol., 65, 90-97.

Jemmi, T. \& Stephan, R. (2006): Listeria monocytogenes: food-borne pathogen and hygiene indicator. Rev. Sci. Technol., 25, 571-580.

Jung, D.S., Bodyfelt, F.W. \& Daeschel, M.A. (1992): Influence of fat and emulsifiers on the efficacy of nisin in inhibiting Listeria monocytogenes in fluid milk. J. Dairy Sci., 75, 387-393.

Kim, E.L., ChOI, N.H., BaJPai, V.K. \& KanG, S.C. (2008): Synergistic effect of nisin and garlic shoot juice against Listeria monocytogenes in milk. Food Chem., 110, 375-382. 
Meena, B., Aparna, V. \& Leora, A.S. (2004): Factors affecting the antilisterial effects of nisin in milk. Int. J. Food Microbiol., 97, 215-219.

Moreno, M.R., Leisner, J.J., Tee, L.K., Ley, C., Radu, S., Rusul, G., Vancanneyt, M. \& De Vuyst, L. (2002): Microbial analysis of Malaysian tempeh, and characterization of two bacteriocins produced by isolates of Enterococcus faecium. J. Appl. Microbiol., 92, 147-157.

SAS Institute, Inc. (1998): SAS User's Guide: Statistics, SAS Institute, Inc., Cary, NC.

Şahingil, D., İșleroĞlu, H., Yildirim, Z., Akçelik, M. \& Yildirim, M. (2011): Characterization of lactococcin BZ produced by Lactococcus lactis subsp. lactis BZ isolated from Boza. Turk. J. Biol., 35, 21-33.

Stiles, M.E. (1996): Biopreservation by lactic acid bacteria. A. Van Leeuw. J. Microb., 70(2-4), 331-345.

Wan, J., Harmark, K., Davidson, B.E., Hillier, A.J., Gordon, J.B., Wilcock, A., Hickey, M.W. \& Coventry, M.J. (1997): Inhibition of Listeria monocytogenes by piscicolin 126 in milk and Camembert cheese manufactured with a thermophilic starter. J. Appl. Microbiol., 28, 273-280.

Yoon, J.I., BAJPAI, V.K. \& Kang, S.C. (2011): Synergistic effect of nisin and cone essential oil of Metasequoia glyptostroboides Miki ex Hu against Listeria monocytogenes in milk samples. Food Chem. Toxicol., 49, 109114. 